\title{
Influence of Learning Model Based on Project and Inquiry is Leading to Skin Literature Ability Based on Learning Learning in Basic School (Experimental Study by Applying STEM-based Learning)
}

\author{
Rif'atunnisa Nur Basyir*, Wardani Rahayu, Durotul Yatima, Adi Apriadi Adiansha \\ Department of Primary Education, State University of Jakarta, Jakarta, Indonesia \\ *Corresponding author: rifhaaddisya7@gmail.com
}

\begin{abstract}
The purpose of this research are knowing effect of Self-directed learning, PJBL model and Guided Inquiry to science literacy abilities. This study was conducted at SDN Cibatok 1 dan Cibatok 6 in April-May 2018. Design of this research is post-test only experiment and control group design. The method that used on this research was quasi experiment. Experiment class was treated by PJBL model, while control class was treated by Guided Inquiry model. This instruments consist questionnaire of self-directed learning and science literacy abilities test. The instruments have been valid and reliable. Analysis data used by Anova 2 ways design (2x2 factorial). The result show that: 1) The ability of science literacy of student who are given PJBL model higher than the students who given Guided inquiry models. (2) There is an enhancement of science literacy of students effected by self-directed learning and learning models. (3) The ability of science literacy of students with high self-directed learning who given treatment PJBL model is higher than the students who are given Guided inquiry model. (4) There is no significant difference the ability of science literacy between students low self-directed learning who given treatment by PJBL model and students who are given treatment by Guided inquiry model.
\end{abstract}

Keywords: guided Inquiry model, PJBL model, self-directed learning, the ability of science literacy

Cite This Article: Rif'atunnisa Nur Basyir, Wardani Rahayu, Durotul Yatima, and Adi Apriadi Adiansha, "Influence of Learning Model Based on Project and Inquiry is Leading to Skin Literature Ability Based on Learning Learning in Basic School (Experimental Study by Applying STEM-based Learning)." American Journal of Educational Research, vol. 6, no. 7 (2018): 1029-1032. doi: 10.12691/education-6-7-21.

\section{Introduction}

The process of science teaching in schools emphasizes the provision of direct experience to develop the competence of learners to better understand the natural surroundings. Broadly speaking, natural science can be defined consisting of three components, namely scientific attitude, scientific process and scientific product. In relation to learning, science should not be glued to concepts. However, providing direct experience in developers of product mastery, process, and scientific attitudes or more broadly mastering science literacy (literacy science).

Literacy of science (a science of literacy) is the knowledge and understanding of scientific concepts and processes necessary for personal decision making, participation, and economic productivity. [1] It is very important to prepare the provision of skills students must have in the 21st century from elementary to college level. The importance of science literacy because of problems related to knowledge and technology. The science literacy in its measurements consists of 3 dimensions of science content, the process of science and the context of science applications.
The measurement of science literacy conducted by the Program for International Student Assessment (PISA) in 2012 puts Indonesia at the bottom of the list of 64 out of 65 participating countries. [2] While the results of PISA 2015 showed an increasing graph. Of the 72 participating countries, Indonesia ranks 8th from bottom. Increased science competence score from 382 in 2012 to 403 in 2015. Measurement of literacy conducted by PISA is used among others to compare literacy of reading, mathematics, and science of students of a country with other participating countries, understanding the strengths and weaknesses of each education system country. The results of the science value obtained by Indonesia either in 2012 or 2015, is still below the average 500 of the value set by PISA. Indonesia only reached Low International Benchmark [2].

The low literacy of science students in Indonesia is caused by several factors such as (1) Weak understanding of students to the basic concept of science; (2) Students only study science limited to theory only students have not been able to apply the concept of science in everyday life; (3) Weakness of students in expressing thoughts in written form and linking information in reading text; (4) Low ability of students in reading, interpreting data in the form 
of pictures, tables, diagrams and other presentation forms; (5) Low ability of students in high-level thinking such as solving problems, scientific reasoning, critical thinking and creative thinking.[3]

The inseparable part of science is technology. Technological developments are based on science while the technology itself supports the development of science, mainly used for discovery activities in an attempt to obtain an explanation of the objects and natural phenomena. Some references indicate that science learning in the context of technology has the potential to increase science literacy. Efforts that can be done is one of them with the use of STEM learning.

As a growing trend in the world of education. STEM learning is used to address real-world situations through a process-based design of problem-solving as used by scientists. Some of the benefits of the STEM is to make students become problem solvers, inventors, innovators, independent, logical thinkers, technology literate, able to connect culture and history of education and be able to connect STEM with the world of work. The application of STEM can be supported by various learning models to improve science literacy, one of which is a project-based learning model and guided inquiry. [4]

The project-based learning model is an innovative learning that emphasizes complex activities with the goal of solving problems based on inquiry activities and producing products. [5] The resulting product can be a student contribution to the improvement of the quality of life. The process of solving problems in the life and manufacture of products can be done individually or in groups. Group work can encourage students to work together but still be responsible for their work independently. Through project-based learning, students have the scientific and technological literacy that appears from reading, writing, observing, and doing science so that it can be used to live in society and solve problems encountered in daily life related to the field of STEM. [6]

The other models are combined in guided inquiry model. The guided inquiry model is considered suitable for science teaching as it encourages students to be more courageous and creative and not only to understand the subject matter but to create the invention. [7]

The guided inquiry learning model in science learning demands students to discover the concepts of science based on the analysis of observed natural phenomena. This learning model provides ample space for students to explore their abilities in learning. Guided inquiry learning can develop intellectual skills and critical thinking of students and students able to solve problems scientifically [8].

The literacy ability of students' science is not only influenced by the instructional model applied by the teacher alone, but also the ability of the students to manage the learning process which is good and efficient. Students' ability to manage their learning well and efficiently is called learning independence. [9] Learning independence is a learning activity that is driven by its own volition, self-choice, and self-responsibility without the help of others and able to account for its actions. [10] Students are said to have been able to study independently if they have been able to do learning tasks without dependence on others. Students who have good learning independence are able to find appropriate and efficient learning strategies, able to gain knowledge from the sources used and be able to motivate themselves to continue to understand the material being studied. Students who have good learning independence also have good science literacy skills. [11]

In learning, teachers can use appropriate and influential models to improve students' learning independence and literacy skills. The high level of student learning independence is expected to improve students' literacy skills. Project-based learning model and guided inquiry are expected to have an influence on the students' literacy skills. The project-based learning model and guided inquiry have stages that emphasize students' science process skills so as to train students to have learning independence, critical thinking, and analysis in solving problems scientifically. Therefore it is necessary to have a research to know the influence of project-based model and guided inquiry on students' literacy skills based on learning independence.

\section{Method}

The research method used in this research is quasi-method of 2X2 factorial design experiment. This study has 3 variables where the independent variable $(\mathrm{X})$ that consists of learning model (X1) and learning independence (X2). While the dependent variable (Y) is Literacy science. The experimental class will be treated with a project-based learning model, while the control class is treated with a guided model of inquiry. Before being treated with the model, the students will be given a self-study learning questionnaire. The research design used in this research is Post Test Only Control Design with 2x2 factorial.

Table 1. Research Design with Factorial 2 x 2

\begin{tabular}{c|c|c}
\hline \multirow{2}{*}{ Motivation (B) } & \multicolumn{2}{|c}{ Learning model (A) } \\
\cline { 2 - 3 } & PJBL (A1) & Guided Inquiry (A2) \\
\hline Highi (B1) & A1B1 & A2B1 \\
\hline Low (B2) & A1B2 & A2B2 \\
\hline
\end{tabular}

The target population in this study were all students of grade V of elementary school in Cibungbulang sub-district, Bogor Regency in the academic year 2017/2018. The affordable population in this study was from 8 elementary schools in Cibungbulang sub-district, randomly sampling was selected by 2 elementary schools, namely SD N Cibatok 1 and SD N Cibatok 6 in the even semester of academic year 2017/2018. Samples were taken from an affordable population by random sampling, from 4 class $\mathrm{V}$ selected 2 classes from each school. Then from each class both the experimental class and the control class selected $27 \%$ of students who have high learning independence and $27 \%$ of students who have low learning independence.

At the end of the study will be given the same test, that is by giving the student literacy skill literacy test. The instruments used in this study have been tested for validity and reliability by experts. The data obtained from this instrument will then be tested using a hypothesis test of two-way ANOVA type. Having previously passed the prerequisite analysis test, the ie test of normality, homogeneity, and average equality. 


\section{Results and Discussion}

Score data of science literacy ability and learning independence between students who were treated with PJBL model and students who were given Inquiry-Guided model.

Table 2. Recapitulation of Science Literacy Scores of Students in Various Classes

\begin{tabular}{c|c|c|c|c}
\hline \multirow{2}{*}{ Scan Literacy Scan range } & \multicolumn{4}{|c}{ Student Relative Frequency } \\
\cline { 2 - 5 } & A1B1 & A1B2 & A2B1 & A2B2 \\
\hline $6-6,5$ & $0 \%$ & $0 \%$ & $0 \%$ & $44 \%$ \\
\hline $6,5-7$ & $0 \%$ & $11 \%$ & $0 \%$ & $55 \%$ \\
\hline $7-7,5$ & $17 \%$ & $33 \%$ & $11 \%$ & $0 \%$ \\
\hline $7,5-8$ & $11 \%$ & $55 \%$ & $33 \%$ & $0 \%$ \\
\hline $8-8,5$ & $27 \%$ & $0 \%$ & $44 \%$ & $0 \%$ \\
\hline $8,5-9$ & $33 \%$ & $0 \%$ & $11 \%$ & $0 \%$ \\
\hline $9-9,5$ & $11 \%$ & $0 \%$ & $0 \%$ & $0 \%$ \\
\hline Average Score & 8,5 & 7,4 & 8,1 & 6,5 \\
\hline Highest score & 9,25 & 8 & 9 & 7 \\
\hline Lowest Score & 7,25 & 6,5 & 7 & 6 \\
\hline
\end{tabular}

Based on Table 2, shows that the average score of science literacy ability of students who have treated model of PJBL of 7.95 while the average score of science literacy ability of students who were treated with guided inquiry model of 7.25. So it can be concluded that the ability of science literacy students who treated PJBL model is higher than the ability of science literacy students who are treated with guided inquiry model.

Table 3. Hypothesis Test Table Anova 2 Direction

\begin{tabular}{l|c|c|c|c}
\hline Source & Df & Mean Square & F & Sig. \\
\hline Corrected Model & 3 & 5.787 & 19.382 & .000 \\
Intercept & 1 & 1977.124 & 6622.350 & .000 \\
Model & 1 & 3.346 & 11.206 & .002 \\
Learning Independence & 1 & 13.830 & 46.324 & .000 \\
Model * Learning Independence & 1 & .287 & .961 & .032 \\
Error & 30 & .299 & & \\
Total & 34 & & & \\
Corrected Total & 33 & & & \\
\hline
\end{tabular}

a. R Squared $=.660$ (Adjusted R Squared $=.626$ )
Hypothesis test of science literacy capability data using PJBL model and guided inquiry model and learning independence done with 2 way ANOVA test can be seen in Table 3.

Two way ANOVA analysis results in Table 3 show that students who were given treatment model of PJBL and Inkuiri model guided to get significance value $=0.002$, then 0.002 . $<0.05$ or Ho is rejected. So it can be said that there are significant differences in the ability of science literacy students if grouped based on learning independence. This result proves the first research hypothesis that there is the influence of learning model on the ability of science literacy student.

From the calculation also obtained that the value of significance for the value of interaction between the learning model with the independence of learning is 0.032 , p-value $<0.05$ means reject $\mathrm{H} 0$ which indicates that there is the interaction between the learning model with learning independence. This result proves second hypothesis that there is interaction of learning model and level of independence of study to ability of student science literacy, thus student's learning independence influence ability of student science literacy, and if given treatment of different learning model, that is with model of PJBL and guided inquiry model, they also affect the ability of science literacy owned by students. This can be seen from Figure 1 below.

Based on Figure 1 shows that there is an interaction between learning independence and learning model. Students who have low learning independence when treated with PJBL model or guided inquiry model will not affect the ability of science literacy. The higher the independence of learning will be the higher the ability of science literacy that is owned, especially groups of students who are treated with model PJBL. Students with high learning independence who are treated with PJBL models will have higher literacy skills in science when compared to students with high learning independence who are treated with guided inquiry models.

\section{Estimated Marginal Means of Tes Kemampuan Literasi Sains}

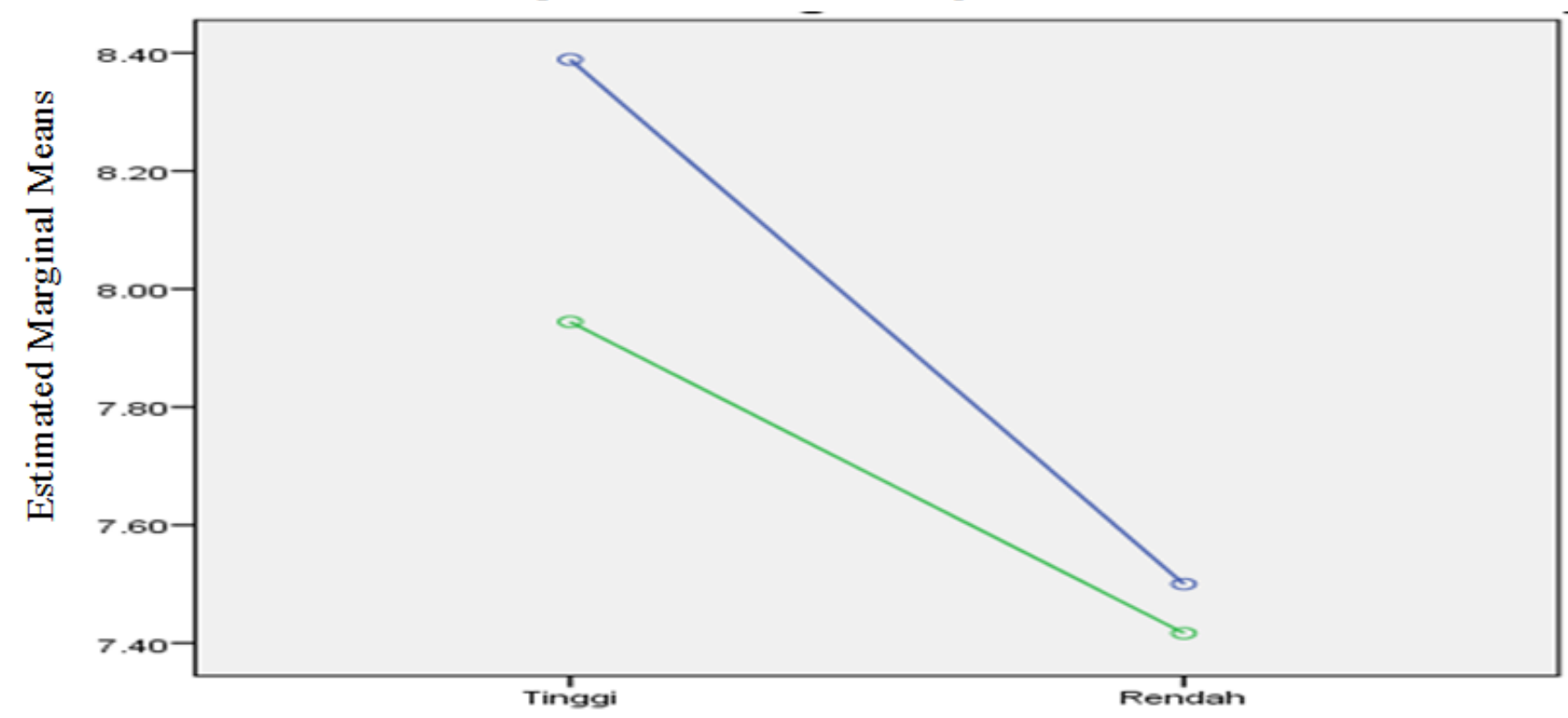

Figure 1. Interaction between learning model and learning independence 
The result of the third hypothesis analysis showed that the students' science literacy ability treated with PJBL model is higher than the literacy ability of the students who are treated with guided inquiry model in the students who have high learning independence. The result of the fourth hypothesis analysis showed that there was no difference of literacy ability of students science between the group of students who were given the treatment with PJBL model and guided inquiry model in students who have low learning independence.

\section{Conclude}

Based on the results of the hypothesis testing and discussion of research, it can be concluded that: (1) The ability of science literacy students who learn with the model PJBL higher than the ability of science literacy students who learn with guided inquiry learning model. This is because there are different steps in the learning process. (2) There is an interaction between learning independence and learning model to the ability of science literacy, that is, there is an influence on the students' science literacy ability on the application of learning model and student learning independence of different height. (3) The literacy ability of science students treated by PJBL model is higher than that of students who are treated in guided inquiry model, in groups of students who have high learning independence due to differences in the application of the problem-solving stage during the learning takes place. (4) There is no influence on the ability of science literacy in students who have low learning independence who are treated with Model PJBL or student guided inquiry learning model.

\section{References}

[1] Becker, K.H. \& Park, K. 2011. Integrative Approaches among Science Technology, Engineering, and Mathematics (STEM) Subject on Students Learning: Meta-Analysis. Journal of STEM Education: Innovation and Research, Vol. 12(5): 23.

[2] OECD. 2012. PISA 2012 Results in Focus What 15-year-olds know and what they can do with what they knowh. h.5.

[3] Rustaman. 2006. Literasi Sains Anak Indonesia. Bandung: FPMIPA UPI.

[4] Morrison J. 2006. "TIES STEM Education Monograph Series: Atributes of STEM Education”. Baltimore, MD: TIES, (2): 5 .

[5] Bell, S. 2010. Project Based Learning for the 21 th Century: Skills for the Future, The Clearing House, Vol. 83: 39.

[6] Hans, Capraro, \& Capraro, M. M. 2015. "How science, technology, engineering, and mathematics (STEM) project-based learning (PBL) affects high, middle, and low achievers differently: The Impact of student factors on achievement”. International Journal of Science and Mathematics Education, Vol. 13(5): 1089.

[7] Carlson, J.L. 2008. Effect of Theme Based Guided Inquiry Instructio on Science. Washington DC: Michigan Technological University.

[8] I.O Matthew and Kenneth. 2012. A Study on The Effect of Guided Learning Teaching Method on Students Achievement in Logic. International Researcher, Vol 2(1): 135.

[9] M. Jeanne, Van Briesen. 2011. Self Directed Learning. Departement of Civil and Evironmental Engineering: Caenegie Mellon University.

[10] Cantwell R.H, \& Archer, J. 2002. The Validation of Measures of Self- Efficacy, Motivation and self-Regulated Learning among Thai tertiary Students. Paper presented at the Annual Conference of the Australian Association for Research in Education.

[11] Gibbons, M. 2002. The Self Directed Learning Handbook: Challenging Adolescent Student to Excel. San Fransisco: CA: Jossey Bass. 